\title{
INVASIVE PLANT SPECIES - THREAT TO GRASSLANDS IN RIVER VALLEYS
}

\author{
Magdalena Szymura, Agnieszka Dradrach, Karol Wolski, Sebastian Świerszcz
}

\begin{abstract}
M. Szymura, A. Dradrach, K. Wolski, S. Świerszcz, Department of Agroecosystems and Green Areas Management, Wrocław University of Environmental and Life Sciences, pl. Grunwaldzki 24 A, 53-363 Wrocław, Poland, e-mail: magdalena.szymura@up.wroc.pl
\end{abstract}

(Received: January 9, 2014. Accepted: March 24, 2014)

\begin{abstract}
River valleys are areas of transition between aquatic and terrestrial communities, with complex biological structure. As ecotones they have high biodiversity as a result of the occurrence of species with different requirements according to soil moisture. They create ecological corridors, allowing migration of the organisms in human disturbed landscape. With these migration routes, species of foreign origin which spread to a new area also benefit. Numerous alien species are considered as invasive, and described as a threat to biodiversity due to strong competitive abilities. To describe the relationships between a number of invasive species, biodiversity and size of a river, the vegetation of $750 \mathrm{~m}$ fragments of the Odra and Dobra river valleys on the area of the Wrocław city were analysed. The comparison of plant communities in the valley of a large, managed river (Odra) and its small tributary (Dobra) was carried out. The plant assemblages, occurring in study areas, determined the habitat conditions on the basis of Ellenberg's indicator values (EIV's), as well as Shannon-Wiener biodiversity index was defined. The designed sites differed according to Shannon-Wiener biodiversity index, as well as soil properties: moisture, reaction, and fertility. In the study side of the Odra river ruderal and scrub species were dominated, whereas in case of study site of the Dobra river - meadows and ruderal species. The invasive plant species occurring in the Odra valley are: Symphoricarpos albus, Solidago gigantea, S. canadensis, Robinia pseudoacacia, Clematis vitalba, Quercus rubra, Reynoutria japonica, Parthenocissus inserta and Echinocystis lobata, and in the Dobra valley: Solidago gigantea, S. canadensis. The analysis of correlation between Shannon-Wiener biodiversity index and share of invasive species revealed statistically significant influence of occurrence of invasive species on biodiversity of plant communities in case of the Odra river.
\end{abstract}

KEY WORDS: river valleys, invasive species, biodiversity, EIV

\section{INTRODUCTION}

Gaining new lands by humans began to transport the species outside of their native ranges. They were helped to cross the barrier, which earlier could not be skipped. Introducing cultivation of the alien plants was caused by economic reasons, it allowed to obtain the substances for medical purposes, or it was connected with cultural grounds (GNIAZDOwSKA 2005). The circumstance, which played the most important role in the whole history of plant species' spread by human, was the discovery of America in 1492. Soon after the discovery of the New World the exchange between continents started. It concerned not only articles, but plant species too (DАјDoK \& ŚLIWIŃSKI 2009). It caused, despite of the intentional introduction of plant species, accidental transport of seeds. Many of European species became casual in America, Asia, Australia, and the other way round - species from these continents invaded Europe (ToKARSKa-GuZIK 2001, DajDOK 2007, ToKarsKa-GuZIK et al. 2012). The change in viewing alien species as welcomed components of the biota to recognizing them as pests and threat to biodiversity has occurred relatively recently. Biological invasions have attracted the attention of scientists only in the last 50 years (PYšEK \& Richardson 2008). Presently, invasions of alien species and landscape fragmentation are one of most important threats to biodiversity at the global scale (ByERs et al. 2002). These processes are caused by human activity and refer to large areas, leading to changes in vegetation and fauna, as well as economic 
losses. Massively occurring invasive species also contribute to changes in the landscape, both in terms of reception aesthetics and functional changes (SzYMURA $\&$ Wolski 2006). The rate and range of widespreading of the invasive species in Central Europe could be explained by changes in land use in post-communist countries in the late 90's. At that time many fields, meadows, and pastures were abandoned, and they created habitats suitable for alien species (KutKowSKA et al. 2006). Invasive plant species, as stronger competitors displace the native species and take their place in ecosystems (DAJDOK \& ŚLIWIŃSKI 2009). River areas are the habitats particularly susceptible to biological invasions because they are adjacent to ecological corridors created by river. (GACKA-GRZESIKIEWICZ 2001, Planty-TABACCHi et al. 2001). Riparian zones appear as key-compartments at the scale of temperate landscapes (Forman \& Godron 1986). These ecosystems are defined as ecotones between aquatic and terrestrial ecosystems (GREGORY et al. 1991, GURNELL 1995). River corridors constitute complex ecological systems. The most important element of these systems is vegetation (TABACCHI et al. 1998). The aim of this study was to assess whether the analysed fragments of large, managed river valley (Odra) and their small tributary (Dobra) differ according to vegetation and share of the invasive plant species.

\section{MATERIAL AND METHODS}

The inventory of vegetation of fragments (750 metres) of both: the Odra river valley (site 1) as well as Dobra (site 2) on the area of Wrocław city (Fig. 1) was done.

Fragments of river valleys with similar land use, currently and in the past, were selected. Fragments designed for analysis are placed in the vicinity of a single-family houses estate. Vegetation is mown every few (2-5) years. In the study areas, 20 sampling plots were placed at the same distance $(35 \mathrm{me}-$ ters) from each other and 10 meters from the river bank. On these plots ( $25 \mathrm{~m}^{2}$ size each) the inventory

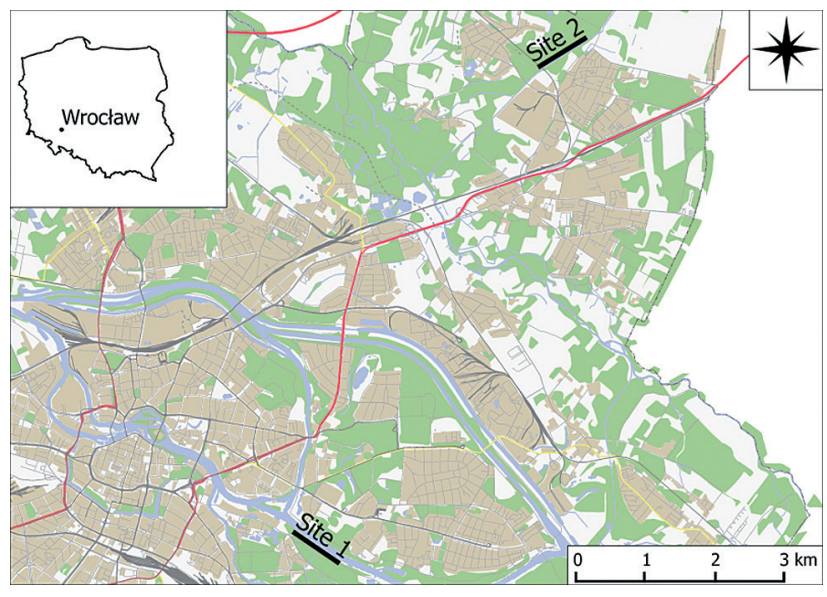

Fig. 1. Location of the study sites of vegetation according to phytosociological method was done. The affiliation of plant species for classes of vegetation was designed (MATUszKIEwicz 2013). On the basis of this analysis the percentage of species representing particular class of vegetation was calculated for each of study sites. Invasive plant species were defined on the basis of "Alien plants in Poland, with special consideration of invasive species" publication (ToKARSKA-GuzIK et al. 2012) and database of alien species in Poland (http://www.iop.krakow.pl/ ias/). The average number of species, Shannon-Wiener (S-W) index of biodiversity, and average of Ellenbergs' indicator values (EIV) were calculated for individual releve (ElLENBERG et al. 1991). Analyses were done using the software of Juice (TicHY 2002). Differences of average values were calculated using the test of Wilcoxon Mann-Whitney, with Monte Carlo permutation by "coin" package in R software (HotHorn et al. 2013). Subsequently the significance of correlations between: index of biodiversity (S-W), average number of species in releve $(\mathrm{N})$, and average number of invasive plant species (ISp), light conditions (EIV_l), temperature (EIV_t $)$, soil moisture (EIV_m), soil reaction (EIV_r), as well as soil nutrient (EIV_n) was calculated for particular plots. For these purposes the Spearman index of correlation was calculated by testing its statistical significance also using the Monte Carlo methods and package "coin".

\section{RESULTS}

In site 1 the occurrence of 140 plant species was noted, among which dominated the ruderal species (Artemisietea vulgaris class), species typical for mesophisous scrubs (Rhamno-Prunetea) and meadows (Molinio-Arrhenatheretea) (Fig. 2), average number of species in releve was 29 (minimal 9, maximal 47). In site 2 occurrence of 98 species was noted, among which majority were meadow (Molinio-Arrhenatheretea class) and ruderal species (Artemisietea vulgaris) (Fig. 2), average number of species in releve was 28 (minimal 22 , maximal 37). The sites do not differ significantly according to the average number of species in releve $(Z=-0.50, p=0.66)$.

In site 1 species with highest cover were grasses: Phalaris arundinacea L., Anthoxanthum odoratum L. and Arrhenatherum elatius (L.) P. Beauv. ex J. Presl et C. Presl, there was noted also considerable cover of invasive plant species: Symphoricarpos albus (L.) S.F. Blake and Solidago gigantea Aiton. The most frequently occurring species were: Festuca rubra L., Dactylis glomerata L. and Calamagrostis epigejos (L.) Roth), and among the invasive species - Solidago canadensis s.l. (Table 1). In site 2 the highest cover was noted in case of Arrhenatherum elatius, Dactylis glomerata, Phalaris arundinacea and invasive species - Solidago gigantea. The most frequently occurring species were, except 


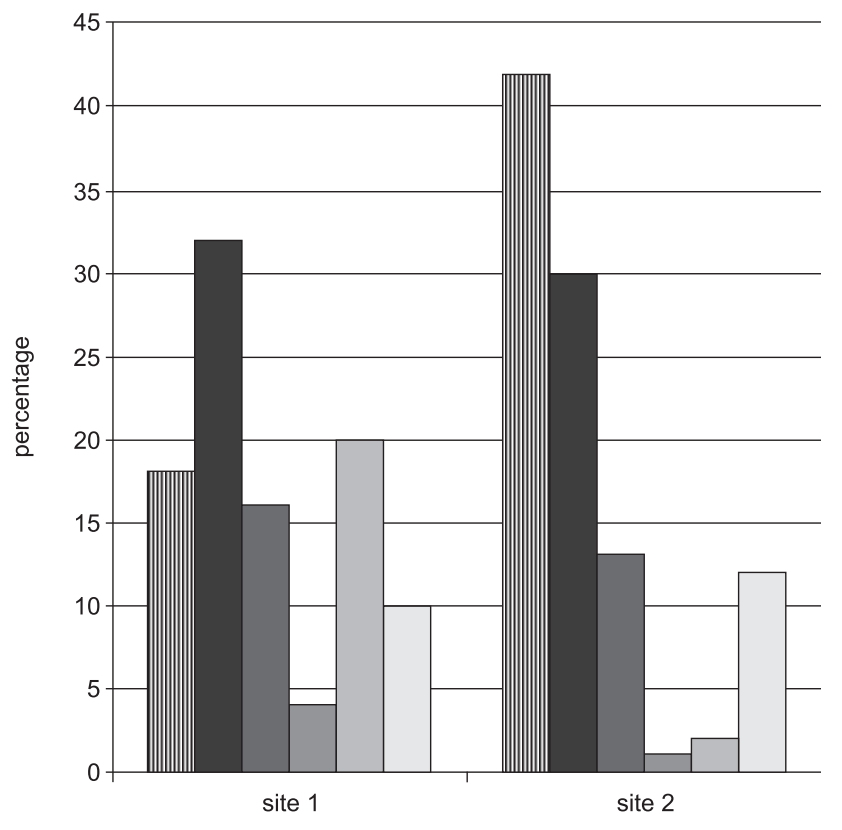

III Molinio-Arrhenatheretea

Artemisietea vulgaris

Phragmitetea

$\square$ Epilobietea angustifolii $\square$ Rhamno-Prunetea $\square$ inne

Fig. 2. Percentage of species typical for particular classes of vegetation in sites 1 and 2

Arrhenatherum elatius and Solidago gigantea, Elymus repens (L.) Gould.) and Ranunculus repens L. (Table 1).

Invasive plant species occurred in $67 \%$ of the analysed plots, with an average cover of $5.3 \%$ (from 0 to $27.6 \%$ ). In site 2 invasive species occurred in all plots, with an average cover of $17.5 \%$ (from 0.01 to $62.5 \%$ ). Due to high variability of values in case of site 2 the differences in average cover of invasive plant species between sites are not statistically significant $(Z=1.28, p=0.21)$.

Study sites differed according to biodiversity $(Z=$ $-2.57, p=0.01)$, the higher value of Shannon-Wie-

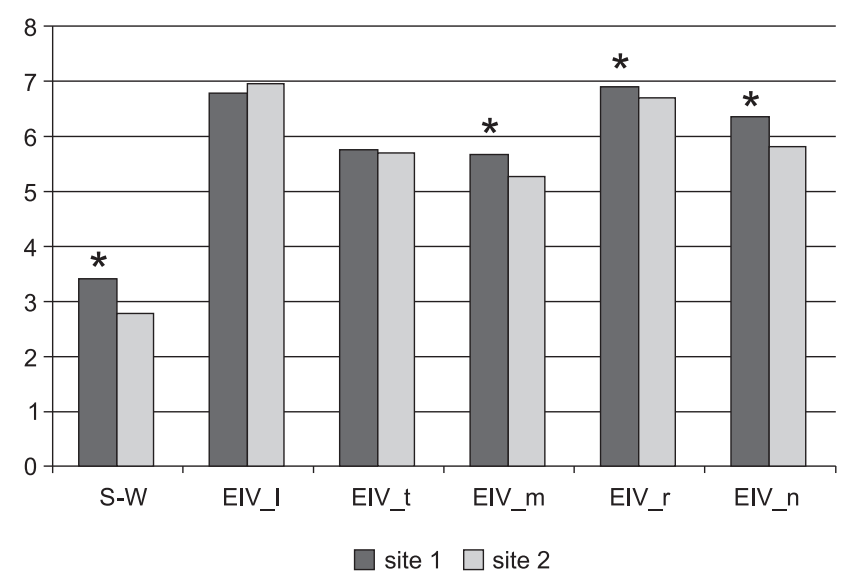

Fig. 3. Values of Shannon-Wiener biodiversity index (S-W) and Ellenberg's indicator values (EIV_l - light, EIV_t - temperature, EIV_m - soil moisture, EIV_r - soil reaction, EIV_n - nutrient contents) for analysed plots in two study sites (site 1 - Odra valley, site 2 - Dobra valley). Statistically significant differences were marked with asterisk ner index was noted in site 1 . Light (EIV_l) and temperature $(E I V t)$ indices are very similar in both sites and do not differ significantly $(Z=1.38, p=0.18$ and $Z=-1.06, p=0.35)$. Soil moisture (EVI_m) is higher in site $1(Z=-2.01, p=0.04)$, as well as soil reaction (EIV_r) $(Z=-2.16, p=0.03)$ and nutrient content (EIV_n) $(Z=-2.43, p=0.00)$ (Fig. 3).

In study site 1 significant correlation between presence of invasive plant species (Isp) and index of biodiversity (S-W), as well as average number of species in releve $(\mathrm{N})$ was noted (Table 2 ). In case of site 2 there was no correlation between occurrence of invasive plant species and biodiversity index (S-W) and number of species. The main factor influencing diversity of plant species was light availability (Table 2).

\section{DISCUSSION}

River valleys have an important function in landscape. They work as ecological corridors and provide the migration of species among distant ecosystems, what maintains natural biodiversity (PLANTY-TABACCHI et al. 2001, BADORA \& NowAK 2004). By the way, invasive species use the corridors for spreading (CHYTRÝ et al. 2008, PyšEK \& Richardson 2008). Presented results show, that in Odra and Dobra River valleys invasive plant species occurred. More species were noted in case of analysed fragment of Odra valley nine taxa (Symphoricarpos albus, Solidago gigantea, Solidago canadensis, Robinia pseudoacacia, Clematis vitalba, Quercus rubra, Reynoutria japonica, Parthenocissus inserta, Echinocystis lobata), whereas in Dobra river valley two taxa were present (Solidago gigantea, S. canadensis). Higher number of invasive plant species along Odra river could be explained by fact, that it is one of the biggest river in Poland and it flows by numerous distributed and human influenced areas. River regulation and stabilization of river banks causes disturbance or create new habitats, where invasive species turn up very fast (CAVAILÉ et al. 2013). It is known that disturbed habitats, where the level of human influence is high, are more suitable for plant invasions (Lake \& Leishman 2004, Hanspach et al. 2008, Chytrý et al. 2009).

Study sites differ significantly according to biodiversity index $(\mathrm{S}-\mathrm{W})$. Site 1 has higher value of biodiversity index, than site 2 . In the Dobra river valley meadows species dominate, in contrast to the Odra river valley, where frequency of this kind of species was lower than ruderal and mezophilous scrubs species. In this site in phytosociological releves tree and shrub species were noted (Salix alba, Prunus spinosa, Symphoricarpos albus, Quercus rubra). It could be the effect of more advanced stage of succession on the studied fragment of Odra river valley, caused by the lack of mowing this area. Additional effect of cessation of mowing the grasslands, beside of the process of succession, is occurrence of invasive plant 
Table 1. Dominant and invasive species in particular sites according to average cover (cover) and frequency of occurrence (freq.). 20 dominant species and all invasive species were shown, which were noted in study sites. Underlined are species listed in Regulation of Ministry of Environment of 9th of September 2011 on the list of non-native species of plants and animals, which, if released into environment, can endanger the native species or habitats

\begin{tabular}{|c|c|c|c|c|c|c|c|}
\hline \multicolumn{4}{|c|}{ Site 1} & \multicolumn{4}{|c|}{ Site 2} \\
\hline No. & species & cover & freq. & No. & species & cover & freq. \\
\hline 1 & Phalaris arundinacea & 17.5 & 13 & 1 & Arrhenatherum elatius & 37.5 & 100 \\
\hline 2 & Anthoxanthum odoratum & 17.5 & 7 & 2 & Dactylis glomerata & 31.8 & 14 \\
\hline 3 & Arrhenatherum elatius & 10.9 & 93 & 3 & Phalaris arundinacea & 18.8 & 29 \\
\hline 4 & Festuca rubra & 8.8 & 100 & 4 & Elymus repens & 12.6 & 100 \\
\hline 5 & Dactylis glomerata & 7.3 & 80 & 5 & Ranunculus acris & 7.6 & 71 \\
\hline 6 & Phragmites australis & 7.0 & 33 & 6 & Calamagrostis epigejos & 6.1 & 43 \\
\hline 7 & Calamagrostis epigejos & 6.5 & 80 & 7 & Urtica dioica & 5.8 & 43 \\
\hline 8 & Phleum pratense & 5.9 & 20 & 8 & Ranunculus repens & 4.4 & 100 \\
\hline 9 & Festuca pratensis & 5.8 & 67 & 9 & Leucantemum vulgare & 3.1 & 71 \\
\hline 10 & Salix alba & 5.6 & 27 & 10 & Holcus lanatus & 3.1 & 71 \\
\hline 11 & Elymus repens & 5.5 & 40 & 11 & Veronica chamaedrys & 2.5 & 43 \\
\hline 12 & Poa palustris & 5.0 & 53 & 12 & Cirsium arvense & 2.5 & 14 \\
\hline 13 & Prunus spinosa & 5.0 & 33 & 13 & Achillea millefolium & 2.5 & 14 \\
\hline 14 & Anthoxanthum odoratum & 5.0 & 7 & 14 & Galium aparine & 2.5 & 14 \\
\hline 15 & Galium aparine & 5.0 & 7 & 15 & Potentilla reptans & 2.5 & 14 \\
\hline 16 & Achillea millefolium & 5.0 & 7 & 16 & Euphorbia cyparissias & 2.5 & 14 \\
\hline 17 & Holcus lanatus & 5.0 & 7 & 17 & Trifolium repens & 1.3 & 57 \\
\hline 18 & Urtica dioica & 5.0 & 7 & 18 & Lamium maculatum & 1.3 & 29 \\
\hline 19 & Rumex acetosella & 5.0 & 7 & 19 & Poa pratensis & 1.3 & 29 \\
\hline \multirow[t]{2}{*}{20} & Alopecurus pratensis & 4.6 & 40 & 20 & Sanguisorba officinalis & 1.3 & 29 \\
\hline & Invasive species: & & & & Invasive species: & & \\
\hline 1 & Symphoricarpos albus & 17.5 & 7 & 1 & Solidago gigantea & 16.8 & 100 \\
\hline 2 & Solidago gigantea & 6.9 & 27 & 2 & Solidago canadensis & 0.1 & 14 \\
\hline 3 & Solidago canadensis & 2.6 & 60 & & & & \\
\hline 4 & Robinia pseudoacacia & 2.6 & 13 & & & & \\
\hline 5 & Clematis vitalba & 1.3 & 27 & & & & \\
\hline 6 & Quercus rubra & 0.1 & 7 & & & & \\
\hline 7 & Reynoutria japonica & 0.1 & 7 & & & & \\
\hline 8 & Parthenocissus inserta & 0.1 & 7 & & & & \\
\hline 9 & Echinocystis lobata & 0.1 & 7 & & & & \\
\hline
\end{tabular}

Table 2. Values of Spearman index of correlation between: index of biodiversity (S-W) and average number of species in releve $(\mathrm{N})$ and the occurrence of invasive plant species (ISp), light index (EIV_l), nutrient content (EIV_n) in analysed plots. Statistically significant values were underlined

\begin{tabular}{llclc}
\hline \multirow{2}{*}{ Factor } & \multicolumn{3}{c}{ Site 1} & \multicolumn{1}{c}{ Site 2} \\
\cline { 2 - 5 } & \multicolumn{1}{c}{$\mathrm{N}$} & $\mathrm{S}-\mathrm{W}$ & $\mathrm{N}$ & $\mathrm{S}-\mathrm{W}$ \\
\hline Isp & $\underline{Z=-2.23, p=0.025}$ & $\underline{Z=-2.02, p=0.044}$ & $Z=1.40, p=0.161$ & $Z=0.87, p=0.385$ \\
EIV_1 & $\underline{Z=-1.81, p=0.030}$ & $Z=-1.75, p=0.081$ & $\underline{Z}=-2.07, p=0.039$ & $\underline{Z=-0.81, p=0.042}$ \\
EIV_t & $Z=1.81, p=0.070$ & $Z=2.06, p=0.069$ & $Z=-0.14, p=0.891$ & $Z=-1.14, p=0.252$ \\
EIV_m & $Z=0.40, p=0.687$ & $Z=0.27, p=0.789$ & $Z=0.74, p=0.458$ & $Z=-0.13, p=0.893$ \\
EIV_r & $Z=1.40, p=0.161$ & $Z=1.35, p=0.176$ & $Z=-0.57, p=0.566$ & $Z=0.71, p=0.480$ \\
EIV_n & $Z=0.68, p=0.497$ & $Z=0.56, p=0.576$ & $Z=0.75, p=0.453$ & $Z=1.54, p=0.122$ \\
\hline
\end{tabular}


species (Faliński 1998, Chytrý et al. 2005, Gerard et al. 2008). These species are often competitively stronger than native ones, and displace native taxa by creating the mono species aggregations (SZYMURA \& Szymura 2013). Good example of this process is the invasion of north American species of Solidago genus. In both study sites the species were present (S. gigantea and S. canadensis). Solidago gigantea, because of wider toleration for soil moisture, occurs more often on river valleys habitats, than S. canadensis (SzYMURA \& Wolski 2006). Goldenrods, invading natural habitats, transform ecosystems due to changing of species composition. It causes significant consequences in changing the number of species of different groups of organisms. Investigations conducted on meadows communities: invaded by Solidago species and without invasive species, show, that domination of invasive plant species causes a decreasing of number of plant species, as well as meadow birds breeding pairs (SKóRKA et al. 2010). It is an effect of the decreasing number of invertebrates, which are the main source of food for birds. Other investigations show, that Solidago species negatively influenced the number and size of ant colonies (LeNDA et al. 2013), as well as the structure of pollinators (Moroń et al. 2009).

Analysis of Ellenberg's indicator values (EVI) suggests occurrence of differences in habitat (according to soil moisture, soil reaction, and nutrient content) in the analysed fragments of the valleys of the Odra and Dobra rivers. In case of the Odra river, values of these indices were higher than in the Dobra valley. It could be connected with the size of the Odra river and high number of its tributaries. A large amount of nutrients and pollutants is transported from whole water catchment into the Odra river. It caused e.g. increase of $\mathrm{pH}$ value and nutrient content.

Consideration of the environment conditions on the basis of Ellenberg's indicator numbers' values (EIV) meets some doubts. The indicator values were calculated based on the observation of species in different conditions. In addition, indicator values for particular species were given for all area of Central Europe (Ellengerg et al. 1991, Diekmann 2003). Despite of it, the Ellenberg's indicator values (EVI) are very often used as a source of knowledge about environmental conditions, when the direct measurements are not possible.

Grasslands are habitats which are dependent on repeated disturbances, e.g. mowing. For this reason, as semi-natural habitats they are more suitable for invasion of alien species, particularly in river valleys (Planty-TABACCHI et al. 2001).

Flood disturbances, occurring in the floodplain, which periodically destroy vegetation, are not a sufficient factor preventing the invasion of alien species on these habitats (GERARD et al. 2008). In order to maintain eligible species composition, grasslands' mowing is necessary.

\section{CONCLUSIONS}

1. In the analysed fragment of the Odra river valley the ruderal and mezophilous shrubs species were dominated, whereas in the Dobra river valley-meadow and ruderal species.

2. In both sites the most frequent species were grasses: Arrhenatherum elatius, Phalaris arundinacea, and Dactylis glomerata.

3. In the analysed plots in the Odra river valley nine invasive plant species occurred, and in the Dobra river valley two. However, in the second case the share of Solidago gigantea was very high (average $16.8 \%$ cover).

4. To avoid the spread of invasive plant species, mowing of inter-embankment areas is necessary.

\section{REFERENCES}

BADora K., NowaK A. (2004): Struktura przestrzenna krajobrazu korytarza ekologicznego doliny Odry z zachodniej części województwa opolskiego. Problemy Ekologii Krajobrazu 14: 143-155.

Byers J.E., Reichard S., Randall J.M., Parker I.M., Smith C.S., Lonsdale W.M., AtKinson I.A.E., SeAstedt T.R., Williamson M., Chornesky E., Hayes D. (2002): Directing research to reduce the impacts of nonindigenous species. Conservation Biology 16: 630-640.

Cavaillé P., Dommanget F., Daumergue N., Loucougaray G., Spiegelberger T., Tabacchi E., Evette A. (2013): Biodiversity assessment following a naturality gradient of riverbank protection structures in French prealps rivers. Ecological Engineering 53: 23-30.

Chytrý M., Jarošík V., Pyšek P., Hájek O., Knollová I., TichÝ L., Danimelka J. (2008): Separating habitat invasibility by alien plants from the actual level of invasion. Ecology 89(6): 1541-1553.

ChytrÝ M., PYšek P., TichÝ L., KNOllová I., DANiHelKa J. (2005): Invasions by alien plants in the Czech Republic: a quantitative assessment across habitats. Preslia 77: 339-354.

Chytrý M., Pyšek P., Wild J., Pino J., Maskell L.C., VILÁ M. (2009): European map of alien plant invasions based on the quantitative assessment across habitats. Diversity and Distribution 15: 98-107.

DАjDok Z. (2007): Rośliny inwazyjne - zieloni najeźdźcy. Zielona Planeta 3(72): 19-24.

DAJDOK Z., PAWLACZYK P. (2009): Inwazyjne gatunki roślin ekosystemów mokradłowych Polski. Wyd. Klubu Przyrodników, Świebodzin.

DAJDOK Z., ŚLIwiŃski M. (2009): Rośliny inwazyjne Dolnego Śląska. Polski Klub Ekologiczny Okręg Dolnośląski, Wrocław.

DiekMANN M. (2003): Species indicator values as an important tool in applied plant ecology - a review. Basic and Applied Ecology 4: 493-506. 
Ellenberg H., Weber H.E., Düll R., Wirth V., Werner W., Paulissen D. (1991): Zeigerwerte von Pflanzen in Mittel-Europa. Scripta Geobotanica 18.

FALIŃSKI J.B. (1998): Invasive alien plants and vegetation dynamics. In: U. Starfinger, K. Edwards, I. Kowarik, M. Wiliamson (eds). Plant invasions: ecological mechanisms and human responses. Backhuys Publishers, Leiden, The Netherlands: 3-21.

Forman R.H., Godron M. (1986): Landscape ecology. Wiley, New York.

GACKA-GRZESIKIEWICZ E. (2001): Jak gospodarować w dolinach rzecznych. Przyroda Polska 8: 16-19.

Gerard M., El Kahloun M., Rymen J., Beauchard O., Meire P. (2008): Importance of mowing and flood frequency in promoting species richness in restored floodplains. Journal of Applied Ecology 45: 1780-1789.

GNIAZDOWSKA A. (2005): Oddziaływania allelopatyczne - „nowa broń” roślin inwazyjnych. Kosmos 54(2-3): 221-226.

Gregory S.V., Swanson F.J., Mc Kee W.A., Cummins K.W. (1991): An ecosystem perspective of riparian zones. Bioscience 41 (8): 540-550.

GuRnell A.M. (1995): Vegetation along river corridors: hydrogeomorphological interactions. In: A.M. Gurnell, G.E. Petts (eds). Changing river Channels. Wiley, Chichester.

Hanspach J., Kühn I., PyšeK P., Boos E., Klotz S. (2008): Correlates of naturalization and occupancy of introduced ornamentals in Germany. Perspectives in Plant Ecology, Evolution and Systematics 10: 241-250.

Hothorn T., Hornik K., van de Wiel M.A., Zeileis A. (2013): Package ‘coin'. Conditional Inference Procedures in a Permutation Test Framework. Available at: http://cran.r-project.org/web/packages/ coin/coin.pdf.

KutKowska B., Tańska-Hus B., Szybiga K., ŁabęDzKI H. (2006): Przemiany społeczno-ekonomiczne w rolnictwie Dolnego Śląska. In: Aktualne problemy rolnictwa, gospodarki żywnościowej i ochrony środowiska. Wyd. AR, Wrocław: 409-428.

LAKE J.C., Leishman M.R. (2004): Invasion success of exotic plants in natural ecosystems: the role of disturbance, plant attributes and freedom from herbivores. Biological Conservation 117: 215-226.

Lenda M., Witek M., Skórka P., Moroń D., WoyCIECHOWSKI M. (2013): Invasive alien plants affect grassland ant communities, colony size and foraging behaviour. Biological Invasion 15: 2403-2414.

Matuszkiewicz W. (2013): Przewodnik do oznaczania zbiorowisk roślinnych Polski. Wyd. Nauk. PWN, Warszawa.

Moroń D., Lenda M., SkóRka P., Szentgyörgyi H., SETTELE J., WOYCIECHOWSKI M. (2009): Wild pollinator communities are negatively affected by invasion of alien goldenrods in grassland landscapes. Biological Conservation 142: 1322-1332.

Planty-Tabacchi A.M., Tabacchi E., Salinas Bonillo M.J. (2001): Invasions of river corridors by exotic plant species: patterns and causes. In: G. Brundu, J. Brock, I. Camarda, L. Child, M. Wade (eds). Plant invasions: species ecology and ecosystem management. Backhuys Publishers, Leiden, The Netherlands: 221-234.

PyšeK P., Richardson D.M. (2008): Invasive plants. In: S.V. Jørgensen, B.D. Fath (eds). Ecological engineering. Vol. 3. Encyclopedia of Ecology. Elsevier, Oxford: 2011-2020.

SkórKa P., Lenda M., TrYjAnOwski P. (2010): Invasive alien goldenroods negatively affect grassland bird communities in Eastern Europe. Biological Conservation 143: 856-861.

Szymura M., Szymura T.H. (2013): Environmental preferences and morphological diversity of goldenrods (Solidago L.) from south-western Poland. Acta Societatis Botanicorum Poloniae 82(2): 107-115.

Szymura M., Wolski K. (2006): Zmiany krajobrazu pod wpływem ekspansywnych bylin północnoamerykańskich z rodzaju Solidago L. Problemy Ekologii Krajobrazu 16: 451-460.

Tabacchi E., Correl D., Hauer R., Pinay G., PlanTY-TABACCHI A.M., Wissmar R. (1998): Role of riparian vegetation in the landscape. Freshwater Biology 40: 497-516.

Tichy L. (2002): JUICE, software for vegetation classification. Journal of Vegetation Science 13: 451-453.

TOKARSKA-GUZIK B. (2001): The history of studies of invasive alien plants in Poland. In: G. Brundu, J. Brock, I. Camarda, L. Child, M. Wade (eds). Plant invasions: species ecology and ecosystem management. Backhuys Publishers, Leiden, The Netherlands: 245-254.

TOKARSKa-GuZIK B., Dajdok Z., ZajĄC M., ZajĄC A., Urbisz A., DANielewicz W., HoŁdyŃsKi C. (2012): Rośliny obcego pochodzenia w Polsce ze szczególnym uwzględnieniem gatunków inwazyjnych. GDOŚ, Warszawa. 